\title{
PROBLEMATIKA PENEGAKAN HUKUM PENATAAN RUANG DALAM PELAKSANAAN OTONOMI DAERAH
}

\author{
(Problematics Law Enforcement of Spatial Planning Law \\ In the Implementation of Regional Autonomy) \\ Suharyo \\ Badan Penelitian dan Pengembangan Hukum dan HAM \\ Kementerian Hukum dan Hak Asasi Manusia \\ JI. HR. Rasuna Said, Kav 4-5 Kuningan Jakarta Selatan 12940 \\ Email : massuharyo@ymail.com
}

Naskah diterima: 3 Juli 2017; revisi: 15 Agustus 2017; disetujui: 22 Agustus 2017

\begin{abstract}
Abstrak
Dalam dinamika kehidupan masyarakat yang semakin berkembang pesat dan maju dengan perekonomian yang membaik, tata ruang menjadi hal yang sangat strategis untuk menccapai ketertiban, keserasian, kesejahteraan, dan ketenteraman masyarakat. Sebagai kebijakan negara telah dikeluarkan Undang-Undang Nomor 26 Tahun 2007 tentang Penataan Ruang. Dalam era otonomi daerah juga telah dikeluarkan Undang-Undang Nomor 32 Tahun 2004 tentang Pemerintahan Daerah jo Undang-Undang Nomor 23 Tahun 2014, dan undang-undang lainnya. Permasalahan yang diangkat dalam penelitian ini adalah bagaimana implementasi undang-undang penataan ruang serta bagaimana pula implementasi undang-undang pemerintahan daerah yang di dalamnya terdapat juga pengaturan tata ruang, serta bagaimana strategi penegakan hukumnya. Metode yang dipakai dalam penelitian ini adalah yuridis normatif. Kesimpulan tulisan ini adalah bahwa penataan ruang harus selaras dengan kepentingan pemerintah pusat, pemerintah daerah provinsi, dan pemerintah kabupaten kota, mengacu pada berbagai peraturan perundang-undangan yang berlaku dan saling berkaitan. Penegakan hukum sangat dimungkinkan melalui berbagai sanksi termasuk sanksi pidana jika terdapat/memenuhi unsur pidana.
\end{abstract}

Kata Kunci : penegakan hukum, tata ruang, otonomi daerah

\begin{abstract}
In the dynamics of people's lives that grows and progresses rapidly with improved economy, the spatial planning becomes very strategic to achieve order, harmony, prosperity and peace of society. As state policy has been issued law Number 26 of 2007 on Spatial Planning. In the era of regional autonomy, Law Number 32 of 2004 on Regional Government jo Law Number 23 of 2014, and other laws had also been issued. The problems raised in this research is how the implementation of spatial law and also how the implementation of local government law in which there is also provision on spatial arrangement and how the law enforcement strategy. The method used in this research is normative juridical. In conclusion the spatial planning should be in harmony with the interests of the central government, provincial and municipal governments, referring to various applicable and interrelated legislation. Law enforcement is possible through various sanctions including criminal sanctions in the presence of criminal elements.
\end{abstract}

Keywords: law enforcement, spatial planning, and regional autonomy 


\section{A. Pendahuluan}

Dalam kehidupan sehari-hari, setiap orang membutuhkan ruang tertentu untuk melakukan kegiatan. Dalam hal ini, ruang dapat diartikan sebagai tempat atau wadah seseorang atau banyak orang untuk melakukan kegiatan, atau secara fungsional ruang dapat diartikan sebagai tempat atau wadah yang dapat yang dapat menampung sesuatu. ${ }^{1}$

Untuk mewujudkan dan menjaga pembangunan yang berkelanjutan, diperlukan penataan ruang secara menyeluruh dan komprehensif. Hal ini telah diantisipasi melalui kebijakan negara dengan pembentukan Undang-Undang No. 26 tahun 2007 tentang Penataan Ruang. ${ }^{2}$ Sebagai tindak lanjut dari Undang-Undang Nomor 26 Tahun 2007, pada tahun 2010 dikeluarkan Peraturan Pemerintah Nomor 15 Tahun 2010 tentang Penyelenggaraan Penataan Ruang. Berkenaan dengan diterapkannya Undang-Undang Nomor 32 Tahun 2004 ${ }^{3}$ tentang Pemerintahan Daerah yang biasa juga disebut Otonomi Daerah, yang sekarang direvisi menjadi Undang-Undang Nomor 23 Tahun $2014^{4}$, diperlukan koordinasi dan harmonisasi yang komprehensif dan intensif para stakeholders.

Hal yang perlu diperhatikan, dalam pemanfaatan ruang wilayah (TRW), secara hierarki, terdiri dari: Rencana Tata Ruang Wilayah Nasional, Rencana Tata Ruang Wilayah Provinsi, dan Rencara Tata Ruang Wilayah Kabupaten/Kota.Berkenaan sangat beragamnya kepentingan nasional, dan kepentingan masyarakat secara meluas, yang harus diakomodasi, maka penataan dan pemanfaatan tata ruang harus memperhatikan, menyelaraskan, memahami, dan mendalami makna yang terkandung dalam berbagai peraturan perundang-undangan lainnya, di antaranya: Undang-undang Nomor 41 Tahun 1999 tentang Kehutanan ${ }^{5}$; Undang-Undang Nomor 31 Tahun 2004 tentang Perikanan; ${ }^{6}$ Undang-Undang Nomor 27 Tahun 2007 tentang Pengelolaan Wilayah Pesisir dan Pantai ${ }^{7}$ jo Undang-Undang Nomor 1 Tahun 2014 tentang Perubahan Atas Undang-Undang Nomor 27 Tahun 2007 tentang Pengelolaan Wilayah Pesisir dan Pulau-pulau kecil; ${ }^{8}$ Undang-Undang Nomor 17 Tahun 2008 tentang Pelayaran; ${ }^{9}$ Undang-Undang Nomor 32 Tahun 2009 tentang Perlindungan dan Pengelolaan Lingkungan Hidup; ${ }^{10}$ Undang-undang Nomor 2 Tahun 2002 tentang Pertahanan Negara; ${ }^{11}$ Undang-Undang Nomor 5 Tahun 1990 tentang Konservasi Sumber Daya Alam Hayati dan Ekosistemnya; ${ }^{12}$ Undangundang Nomor 21 Tahun 2001 tentang Otonomi

\footnotetext{
1 Robert Kondoatie \& Roestam Syarief, Tata Ruang Air, Pengelolaan Bencana, Pengelolaan Infrastruktur, Penataan Ruang Wilayah, Pengelolaan Lingkungan Hidup (Yogyakarta: Andi, 2010) hlm. 399.

Lihat Undang-undang Nomor 26 Tahun 2007 tentang Penataan Ruang.

Lihat Undang-undang Nomor 32 Tahun 2004 tentang Pemerintahan Daerah.

Lihat Undang-undang Nomor 23 Tahun 2014 tentang Pemerintahan Daerah.

Lihat Undang-Undang Nomor 41 Tahun 1999 tentang Kehutanan.

Lihat Undang-Undang Nomor 31 Tahun 2004 tentang Perikanan.

Lihat Undang-Undang Nomor 27 Tahun 2007 tentang Pengelolaan Wilayah Pesisir dan Pantai.

8 Undang-undang Nomr 1 Tahun 2014 tentang Perubahan Atas Undang-Undang Nomor 27 Tahun 2007 Tentang Pengelolaan Wilayah Pesisir dan Pulau-pulau Kecil.

Lihat Undang-Undang Nomor 17 Tahun 2008 tentang Pelayaran.

10 Lihat Undang-Undang Nomor 32 Tahun 2009 tentang Perlindungan dan Pengelolaan Lingkungan Hidup.

11 Lihat Undang-Undang Nomor 2 Tahun 2002 tentang Pertahanan Negara.

12 Lihat Undang-Undang Nomor 5 Tahun 1990 tentang Konservasi Sumber Daya Alam Hayati dan Ekosistemnya.
} 
Khusus Bagi Provinsi Papua; dan ${ }^{13}$ UndangUndang Nomor 11 Tahun 2006 tentang Provinsi Aceh. ${ }^{14}$

Penerapan tata ruang di tengah keberlangsunganotonomidaerah, dalam praktek di lapangan bisa terjadi perbedaan persepsi. Pada aspek tata ruang, tujuannya adalah untuk menertibkan dan mengendalikan penataan ruang di Indonesia. Sementara itu dalam aspek otonomi daerah, penataan ruang dilaksanakan secara sistematik untuk kepentingan masyarakat utamanya di daerah sendiri. Karena itu dapat dan bisa terjadi kepentingan pemanfaatan tata ruang di daerah, tidak sama dan tidak selaras, bahkan bertentangan dengan rencana tata ruang nasional, rencana tata ruang provinsi, juga bertentangan dengan rencana tata ruang daerah sekitar.

Dari berbagai kasus tata ruang, setidaknya daerah-daerah dengan potensi ekonomi dan perdagangan nasional serta internasional, termasuk pembangunan industri, perumahan/ permukiman, dan pariwisata, menjadi ajang pemberitaan. Rencana reklamasi laut di Benoa Bali, Makassar sudah lama menimbulkan resistensi dari berbagai pihak. Reklamasi laut yang sangat menarik perhatian secara nasional, dan berlangsung intens dan serius tidak lain berkenaan pembangunan reklamasi Pulau $\mathrm{G}$ di utara Jakarta.

Reklamasi Teluk Jakarta, berawal dari Keputusan Presiden Nomor 52 Tahun 1995, yang pada gilirannya Gubernur DKI Jakarta Basuki Tjahaja Purnama, memproses dan memberi izin pada beberapa pihak swasta untuk melakukan reklamasi melalui Surat Keputusan
(SK) Gubernur DKI Jakarta Nomor 2238 Tahun 2014. Pulau-pulau hasil reklamasi adalah A, B, C, D, E, F, G. Proyek reklamasi yang sudah selesai adalah Pulau G. Sementara pulau-pulau yang lain sudah ada pembangunan rumah, kawasan perkantoran dan pergudangan, walaupun belum selesai. ${ }^{15}$

Secara implisit dan eksplisit, terhadap pembangunan fisik dengan pemanfaatan lahan yang sudah lama berjalan, dan sampai sekarang ini terus berlangsung dimungkinkan adanya dispensasi berkenaan kebutuhan lahan, walaupun peruntukan lahan tersebut semula bisa jadi untuk kebutuhan yang lain. Perencanaan dan penelitian yang telah dilakukan pada masa lalu untuk menjawab kebutuhan sekarang bisa diubah oleh birokrasi yang berwenang, melalui perubahan peraturan perundang-undangan tertentu.

Suatu permasalahan yang dapat diidentifikasi dalam penelitian hukum ini, yang pertama, bagaimana implementasi Undang-undang Nomor 26 Tahun 2007 Tentang Penataan Ruang, dan bagaimana pula dengan implementasi Undang-Undang Nomor 32 Tahun 2004 jo Undang-undang Nomor 23 Tahun 2014 tentang Pemerintahan Daerah dalam penegakan tata ruang, serta terkait dengan berbagai peraturan perundang-undangan yang ada, diantaranya Undang-Undang Nomor 1 Tahun 2014 Tentang Perubahan Atas Undang-Undang Nomor 27 Tahun 2007 tentang Pengelolaan Wilayah Pesisir dan Pulau-pulau Kecil, dan berbagai undang-undang lainnya. Yang kedua, bagaimana strategi penegakan hukum tata ruang di tengah dinamika otonomi daerah.

\footnotetext{
13 Lihat Undang-Undang Nomor 21 Tahun 2001 Tentang Otonomi Khusus Bagi Provinsi Papua.

14 Lihat Undang-Undang Nomor 11 Tahun 2006 Tentang Provionsi Aceh.

15 Forum Keadilan Nomor 12, 25 Juli - 07 Agustus 2016
} 


\section{B. Metode Penelitian}

Untuk menjawab permasalahan penegakan hukum penataan ruang dalam pelaksanaan otonomi daerah, penelitian ini menggunakan metode penelitian hukum normatif. Suatu penelitian hukum normatif atau penelitian hukum kepustakaan adalah penelitian hukum yang dilakukan melalui penelitian bahan pustaka atau data sekunder. Penelitian hukum normatif tersebut mencakup penelitian terhadap asasasas hukum, penelitian terhadap sistematika hukum, penelitian terhadap taraf sinkronisasi vertikal dan horizontal, perbandingan hukum, dan sejarah hukum. ${ }^{16}$

Adapun data yang diperoleh berasal dari literatur terpilih dan terkait dengan judul penelitian. Di samping itu juga dengan mencermati berbagai perundang-undangan yang terkait dan relevan serta menganlisis data yang berasal dari surat kabar yang memberitakan dinamika tata ruang.

\section{Pembahasan}

\section{Implementasi Penataan Ruang}

Sebagai fenomena umum pemanfaatan ruang di Indonesia, masih dan terus terjadi bersinggungan bahkan bertolak belakang antara aspek penataan ruang dan kebutuhan ruang dalam pembangunan, termasuk dalam memenuhi kebutuhan masyarakat sendiri. Serangkaian persoalan yang menyelimuti pelanggaran tata ruang, termasuk dalam pelaksanaan otonomi daerah, serta berbagai peraturan perundang-undangan lainnya.

Sebagai contoh, bertambahnya industri pariwisata di Indonesia tak hanya menimbulkan dampak positif, tetapi juga efek negatif bagi masyarakat. Hal ini disebabkan pembangunan sektor pariwisata dilakukan tanpa perencanaan yang matang, bahkan sering melanggar tata kota yang ditetapkan sendiri oleh pemerintah daerah.

Kondisi itu salah satunya terlihat di Kota Cirebon, Jawa Barat. Peningkatan kunjungan pariwisata ke "Kota Udang" itu mengakibatkan pembangunan hotel, penginapan, dan restoran tak terkendali. Saat ini kota yang luasnya hanya 27 kilometer persegi itu memiliki lebih dari 60 hotel. Ini berarti dalam 0,45 kilometer persegi terdapat satu buah hotel. Selain hotel, di kota Cirebon juga terdapat 130 restoran.

Pertumbuhan hotel dan restoran yang tidak diikuti dengan ketersediaan lahan parkir dan sumber airyang memadai, mengakibatkan setiap akhir pekan kemacetan selalu terjadi di sejumlah ruas jalan, seperti Jalan Ciptomangunkusumo dan Jalan Kartini. Masyarakat kekurangan air bersih karena pasokan air yang sebelumnya hanya untuk rumah tangga, kini, harus dibagi untuk hotel dan restoran. PDAM Kota Cirebon mencatat, dari 18,15 juta meter kubik air yang diproduksi, 16 persen dipasok ke industri, termasuk perhotelan. Sementara sumber air bersih hanya berasal dari Paiis, kabupaten Kuningan. Pasokan air dari Paniis pun tidak bertambah, tetap 1.061 liter per detik.

Krisis air akibat pertumbuhan hotel yang tak terkendali juga dialami oleh warga Yogyakarta, terutama warga yang tinggal di wilayah Miliran, Muja-muju, dan Umbulharjo. Sejak hotel berdiri tahun 2014, sumur warga selalu kekeringan. Sementara di Bandung, penambahan hingga 200 hotel dalam lima tahun terakhir

16 Soerjono Soekanto dan Sri Mamudji, Penelitian Hukum Normatif Suatu Tinjauan Singkat (Jakarta Raja Grafindo Persada, 2006) hlm. 13-14. 
menimbulkan kemacetan di banyak ruas jalan. Bahkan pertumbuhan hotel yang tak terkendali juga mengakibatkan banjir.

Ancaman bencana alam di berbagai daerah telah terjadi. Kerusakan lingkungan semakin tidak terkendali. ${ }^{17}$ Menteri Pekerjaan Umum dan Perumahan Rakyat Basuki Hadimulyono mengatakan semua pihak agar menjaga kawasan tangkapan air. Saat ini ada 22 daerah aliran sungai di Indonesia yang kondisinya kritis. Kerusakan daerah tangkapan air menjadi penyebab utama banjir dan longsor di seluruh daerah, contoh yakni daerah Bima (Nusa Tenggara Barat dan Pati).

Menurut Basuki, alih fungsi kawasan dan pengelolaan yang salah menjadi penyebab rusaknya kawasan tangkapan air. la mencontohkan sistem pertanian apa adanya disekitar hulu Sungai Brantas, di Batu, berpotensi menyebabkan sidementasi. "Seharusnya diatur, bukan dilarang, melainkan diatur, misalnya dengan terasering atau cara tanam lebih baik lainnya", ucapnya.

Hujan yang terus menerus juga memicu pergerakan tanah di Desa Batu Hampar, Kecamatan Kayu Aro Barat, Kabupaten Kerinci, Jambi. Paling tidak 24 keluarga mengungsi karena rumah rusak dan retak-retak. Di Papua, badan sungai yang longsor menyebabkan jembatan Kali Wunim di Kabupaten Tolikara, ambruk, Kamis. Akibatnya akses jalan darat dari Karubaga, ibukota Tolikara ke delan distrik terputus.

Kerusakan dan perusakan lingkungan, termasuk yang dilakukan oleh masyarakat untuk meningkatkan kehidupannya juga berlangsung di berbagai daerah. Kerusakan hutan lindung akibat penambangan liar di sejumlah daerah kian masif. Kerusakan itu tidak hanya sebatas kehancuran lingkungan di kawasan, tetapi juga pencemaran yang luar biasa akibat penggunaan sianida dan merkuri.

Tambang emas liar yang muncul di sejumlah daerah di Maluku telah merusak lingkungan hingga mengancam keamanan pangan. Namun tidak ada keseriusan pemerintah daerah dalam menangani dampaki tambang liar. Bahkan sejumlah lokasi pertambangan belum berhasil ditutup. Lokasi tambang emas liar umumnya ada di Pulau Buru, tepatnya di Kabupaten Buru, yakni Gunung Botak, Gunung Nona, dan Gogorea. Selain itu, juga ada tambang batu sinabar di Luhu-Iha, Pulau Seram, Kabupaten Seram Bagian Barat, Gunung Botak dan Gogorea sudah ditutup, sementara Gunung Nona dan Luhu-Iha masih beroperasi.

Kepala Kepolisian Resort Pulau Buru Ajun Komisaris Besar Leo Simatupang mengatakan bahwa aktivitas tambang di Gunung Botak mengakibatkan penambangan itu, bukit setinggi lebih kurang 500 meter, terbelah sehingga membentuk jurang dan kedalaman jurang hampir $\mathbf{3 0 0}$ meter dari puncak bukit. Material tanah dari bukit itu dibawa ke lereng dan diolah menjadi emas menggunakan merkuri dan sianida. Hutan sagu dijadikan tempat pengolahan material. Akibatnya, sagu-sagu itu mati.

Penataan dan pemanfaatan tata ruang, ternyata juga menimbulkan konflik berkepanjangan antara warga masyarakat dengan pemerintah daerah. ${ }^{18}$ Presiden Joko Widodo telah memerintahkan agar dilakukan kajian lingkungan hidup strategis di Pegunungan

Harian Kompas, “Kondisi 22 Aliran Sungai Kritis”, Sabtu 7 Januari 2017.

18 Harian Kompas, "Semua Pihak Harus Tunggu Hasil Kajian”, Kamis 16 Maret 2017. 
Kendeng Jawa Tengah. Hasil kajian akan menjadi dasar untuk menentukan zonasi kawasan yang boleh ditambang dan tidak boleh ditambang di Gunung Kendeng. Oleh sebab itu, pengoperasian pabrik semen di kawasan itu harus menunggu hasil kajian ini. "Tim Saat ini sedang bekerja untuk menyelesaikan kajian lingkungan hidup Strategis (KLHS) sebagaimana diperintahkan Presiden. Latar belakang dibentuknya KLHS ini sebenarnya untuk memediasi konflik lingkungan ataupun sosial dengan pertimbangan ilmiah", kata Sudharto P Hadi.

Selain bencana alam yang telah disebutkan di atas, bencana longsor menjadi salah satu ancaman nyata. Sebagai contoh, pada bulan Maret lalu sebanyak 27 orang tertimbun longsor di Desa Banaran, Kecamatan Pulung, Kabupaten Ponorogo, Jawa Timur. Menyusul setelah itu tebing setinggi 100 meter ambrol dan menimpa permukiman warga akibat hujan deras. Semua korban belum ditemukan. Selain itu ada 17 warga lainnya yang berhasil menyelamatkan diri, menderita luka dan kini di rawat di Puskesmas. Longsor ini juga menghantam dan merusak 35 rumah. Puluhan hewan milik warga setempat juga tertimbun material longsor.

Kepala Pusat Data Informasi dan Humas Badan Nasional Penanggulangan Bencana (BNPB) Sutopo Purwo Nugroho mengatakan, pukul 07.30, gerakan tanah mulai terjadi di wilayah itu yang diikuti bunyi gemuruh. Sebagian warga langsung mengungsi. Pada pukul 08.00, bencana longsor besar mulai terjadi, menerjang permukiman dan ladang warga RT.002 dan 003 di RW 01 tersebut

Pengampanye Greenpeace Indonesia di Papua, Charles Tawau, mengatakan, Papua dan
Papua Barat, kini dijejali 48 perkebunan sawit. Luasnya 25.000-45.000 hektar per perkebunan. Ancaman terhadap Sorong dan Fakfak yang disiapkan menjadi kawasan ekonomi khusus juga merupakan satu hal yang nyata. Pembangunan berbagai infrastruktur perindustrian dan sarana umum itu dipastikan akan menggunakan hutanhutan di Papua. ${ }^{19}$

Pembangunan lain, seperti Merauke Integrated Food and Energy Estate, membuktikan pengalaman pembukaan lebih dari 2 juta hektar hutan di selatan Papua. Direktur Eksekutif Yayasan Pusaka Franky Yafet Samperante juga menunjukkan pembukaan lahan di Boven Digoel seluas 2.400 hektar untuk perkebunan sawit. Selain meningkatkan deforestasi, pembukaan lahan ini menimbulkan konflik sosial dengan warga.

Selama periode 1990-2000, pemberian IUPHHK-HA dominan. Namun setelah tahun 2000, izin lahan perkebunan sawit banyak diberikan. Menurut Zulfikar, 95\% pemberian berbagai izin itu dilakukan secara terencana. Umumnya, izin diberikan 1-2 tahun menjelang Pemilu Kepala Daerah. Baik pemerintah pusat maupun daerah, katanya, sama-sama punya andil atas rusaknya hutan di tanah Papua.

Di sisi lain, Provinsi Papua dan Papua Barat, memiliki potensi emisi gas rumah kaca masingmasing 17,4 gigaton dan 6 gigaton karbon dioksida. Jika 10 persen saja dari potensi emisi itu lepas ke atmosfir, akan menambah jumlah emisi Indonesia sebesar 2,34 gigaton karbon dioksida. Meski sangat berisiko, hampir tak ada program mitigasi perubahan iklim yang dilakukan di Tanah Papua.

19 Ichwan Susanto dan M Said Wahyudi dalam Kompas, "Hutan Papua Penentu Emisi Indonesia”, Minggu 16 April 2017. 
Karena itu, Zulfikar mengingatkan, jika Indonesia tak melakukan upaya nyata untuk menjaga dan memelihara Indonesia dalam pengelolaan hutan di Sumatera dan Kalimantan yang sudah hancur akan terulang kembali. Direktur Eksekutif Wahana Lingkungan Hidup Indonesia (WALHI) Nur Hidayati, mengatakan, masyarakat adat punya andil besar dalam menjaga lingkungan tetap lestari. Hutan mangrove, gambut, atau terumbu karang yang terjaga akan mengurangi emisi gas rumah kaca yang dihasilkan, sehingga Indonesia mampu berperan aktif dalam menghadapi dampak perubahan ilkim global.

Praktik-praktik sederhana yang dilakukan masyarakat adat sudah terbukti mampu menjaga lingkungannya lestari. Seperti masyarakat adat Knasaimos di Manggroholo, Sorong Selatan, Papua Barat, mereka secara bulat melindungi hutan sagu dan damar dari ekspansi perusahaan perkebunan sawit.

Sedangkan tentang tata ruang di Jakarta, yang sangat mendominasi pemberitaan secara meluas seluruh media massa Indonesia termasuk media internasional, tidak lain tentang reaksi keras dari berbagai kelompok masyarakat Jakarta dan penolakan terhadap reklamasi pembuatan 9 (sembilan) pulau di Jakarta. LBH Jakarta menolak reklamasi tersebut, dengan berbagai alasan. ${ }^{20}$ Penolakan terhadap reklamasi tersebut berlanjut sampai di Pilkada DKI Jakarta, yang akhirnya dimenangkan oleh Anis Baswedan dan Sandiaga Uno.

Sejumlah daerah di Kota dan Kabupaten bandung Jawa Barat, kini semakin mudah dilanda banjir. Saat curah hujan tidak terlalu banyak berubah, daya dukung lingkungan yang buruk dan kebiasaan warga membuang sampah sembarangan diduga menjadi pemicu. Kepala balai Hidrologi dan Tata Air di Pusat Penelitian dan Pengembangan Sumber Daya Air Irfan Sudono mengatakan, curah hujan ekstrim bukan penyebab utama banjir di Bandung dan sekitarnya. Data hujan tahunan justru menunjukkan tren penurunan curah hujan sekitar 200 milimeter dalam rentang 50 tahunan. Alih fungsi lahan untuk permukiman dan pembangunan lain memicu banjir. Kepala Balai Besar Wilayah Sungai Citarum Yudha Mediawan menyebutkan jumlah lahan kritis di Daerah Aliran Sungai Citarum mencapai 26022 hektar pada tahun 2016. Kondisi ini memicu erosi lahan. ${ }^{21}$

\section{Implementasi Otonomi Daerah}

Eko Prasodjo menyatakan, ${ }^{22}$ di Negara Kesatuan tidak mungkin terdapat materi urusan pemerintahan (fungsi) yang hanya dilakukan secara desentralisasi tanpa sentralisasi, artinya, selalu terdapat wewenang mengatur, sekalipun diselenggarakan dengan atau melalui asas desentralisasi. Dengan kata lain, pemerintah pusat secara eksklusif dapat memiliki wewenang mengatur dan mengurus secara mutlak, dan tidak pernah terjadi daerah otonom memiliki suatu wewenang yang eksklusif. Hal ini berbeda dengan negara federal, dimana baik pemerintah federal maupun pemerintah negara bagian masing-masing secara eksklusif dapat memiliki wewenang mengatur dan mengurus untuk

\footnotetext{
20 LBH Jakarta, "19 Alasan Tolak Reklamasi Jakarta", https://www.bantuanhukum.or.id/web/19-alasan-tolakreklamasi-jakarta/, diakses tanggal 20 juni 2017.

21 Kompas, "Bandung Mudah Banjir", Jumat 5 Mei 2017.

22 Eko Prasodjo, Reformasi Kedua Melanjutkan Estafit Reformasi (Jakarta: Salemba Humanika, 2009$)$ hlm. 144.
} 
satu materi urusan. ${ }^{23}$ Pemerintah daerah selain berperan melindungi masyarakat dan menyerap aspirasi masyarakat, juga harus mampu mengelola berbagai kewenangan yang diberikan dan dipercayakan oleh pemerintah pusat kepadanya. Dalam pengelolaan kewenangan yang luas tersebut tetap dibatasi rambu penting dalam kerangka Negara Kesatuan Republik Indonesia.

Implementasi Undang-undang Nomor 26 Tahun 2007 tentang Penataan Ruang, banyak terkendala. Pelaku pelanggaran sangat bervariasi, bisa warga masyarakat, pelaku usaha, dan jajaran pemerintahan sendiri. Ada yang saling berkolaborasi dan banyak pula yang bertindak sendirian. Pemerintah Daerah yang menikmati era otonomi daerah, dalam beberapa hal melalui produk Peraturan Daerah Provinsi dan Keputusan Gubernur, dan juga Peraturan Daerah Kabupaten/Kota dan Keputusan Bupati/Walikota bisa jadi melanggar penataan ruang, dan tidak memperhatikan berbagai peraturan perundang-undangan di atasnya. Hal mana berkenaan walaupun secara tersurat bahwa pemerintah daerah wajib mematuhi dan melaksanakan tata ruang wilayahnya, namun dalam aspek kepentingan nasional, bangsa, dan negara sesungguhnya tata ruang adalah beraspek nasional demi kesejahteraan dan kedamaian seluruh masyarakat Indonesia.

\section{Strategi Penegakan Hukum}

Penegakan hukum pelanggaran penataan ruang, selama ini masih dikedepankan sanksi administratif yang berdasarkan sanksi-sanksi dari Perda oleh Pemerintah Daerah Kabupaten/ Kota. Untuk sanksi perdata berupa ganti rugi ataupun pemulihan seperti kondisi semula, masih jarang/belum pernah terjadi. Yang lebih banyak bermunculan, hanya berupa pernyataan telah terjadi kerusakan lingkungan, pelanggaran tata ruang, dan saling berbeda pendapat diantara para pihak. Sementara bencana alam dan kerusakan lingkungan dan ketidak tertiban tata ruang, tidak segera diselesaikan.

Aspek hukum memberikan justifikasi dari suatu proses pembangunan. Dengan kata lain, produk pembangunan akan berdampak pada produk hukum yang ada serta dimungkinkan dilakukan perubahan-perubahannya. Proses hukum dapat berjalan dengan baik kalamana hukum memberikan rasa keadilan terhadap pihak-pihak yang terkait. Lembaga-lembaga pembuat peraturan bisa melakukan perubahan, penyempurnaan atau pencabutan terhadap peraturan yang sudah ditetapkan itu, bila ternyata dalam pelaksanaannya tidak menunjukkan rasa keadilan bagi pihak yang terkait, atau terdapat kekeliruan dalam penetapannya. Persoalan hukum menjadi sangat penting ketika terjadi konflik, baik konflik kepentingan, konflik antar pengguna, dan lain-lain. Aspek hukum berbenturan dengan aspek sosial, ekonomi, dan lingkungan. ${ }^{24}$

Penegakan hukum terhadap pelanggarantata ruang, adalah salah satu pilihan hukum terbaik. Namun dalam aspek tata ruan, tidak selamanya beranjak dari hukum. Adapun telaahan kritis 
terhadap ketentuan undang-undang penataan ruang adalah sebagai berikut: ${ }^{25}$

1. Tata ruang merupakan konsep dinamis oleh karena dipengaruhi oleh kondisi sosial, ekonomi, dan budaya serta teknologi, sehingga dalam pelaksanaannya tata ruangt hendaknya memperhatikan kondisi-kondisi tersebut;

2. Dalam penerapan konsep tata ruang tidak dapat dilakukan secara kaku atau rigid, oleh sebab itu secara periodik membutuhkan rivisi berdasarkan cakupan tentang alam dan perkembangan teknologi dalam membangun lingkungan buatan;

3. Dalam hal visi, pengendalian dengan memperhitungkan daya tampung dan daya dukung lingkungan tetap sebagai acuan normatif;

4. Dalam menentukan ketentuan sanksi, hendaknya memperhitungkan ketentuan dari Undang-Undang Tata Usaha Negara, terkecuali jika suatu tindakan yang berkaitan dengan penataan terdapat tindakan yang mengandung unsur-unsur pidana.

Konsep pembangunan selama ini masih menyimpan persoalan. Pertama, bersifat parsial dan menyendiri. Setiap proyek pembangunan, yang ditangani secara terpisah, memang dikalkulasi dengan baik dan berdaya guna. Namun, begitu tergabung dengan proyekproyek lain, semuanya menjadi goyah terobangambing dalam arus kehidupan yang dalam kenyataan memadukan setiap usaha dalam satu jaringan keterkaitan. Ternyata setiap proyek pembangunan hanya solid dalam kesendirian masing-masing. ${ }^{26}$
Kedua, mengabaikan aspek human dari rakyat (manusia) Indonesia. Pembangunan katanya memang bertujuan memenuhi kebutuhan rakyat akan pangan, sandang, papan, kesehatan, dan pendidikan. Proses pembangunan kerap lupa bahwa manusia dalam kehidupannya tidak hanya butuh "to have more", tetapi juga "to be more", lebih-lebih bagi mereka yang sudah merasa terdidik.

Ketiga, tidak dikaitkan sama sekali dengan konsep "Nation-State building", tetapi dengan kenaikan GNP, seolah-olah dengan kenaikan pendapatan nasional negara-bangsa sebagai satu entitas dengan sendirinya menjadi semakin kukuh.

Keempat, mengabaikan etika masa depan, yaitu etika yang harus dihayati sekarang untuk dan demi masa depan. Generasi sekarang selalu merasa dirinya menjadi pewaris dari kekayaan alam Tanah Air dan karena itu merasa berhak mengeksploitasi seenaknya kekayaan tersebut. Padahal, ia harus menyadari dirinya bukan pewaris, tetapi peminjam dari generasi masa depan.

Kelima, memang memanfaatkan penalaran aneka disiplin ilmiah, jadi kerja pembangunan bersifat multidisipliner. Namun, mempercayai satu disiplin sebagai "pemimpin" dalam berfikir dan bertindak interdisipliner, yaitu ekonomika (economics). Tentu bisa saja di satu proyek, di satu tempat, selama satu periode tertentu, kakayaan multidisipliner menjadilintasdisipliner, dimana satu disiplin (ekonomika) dianggap "leading" karena ia yang paling berpotensi menjadi penggerak awal mekanisme kerja. Tetapi dalam periode selanjutnya ia mungkin

\footnotetext{
25 H. Juniarso Ridwan \& Achmad Sodik, Hukum Tata Ruang Dalam Konsep Kebijakan Otonomi Daerah (Bandung: Nuansa Cendekia, 2016) hlm. 59.

26 Daoed Joesoef, Studi Strategi Logika Ketahanan dan Pembangunan Nasional (Jakarta: Penerbit Buku Kampus, 2014).
} 
diganti oleh sisiplin lain yang dipercaya menjadi penentu bagi keberhasilan final, misalnya, antropologi, dan lain-lain.

Pendalaman terhadap penataan ruang dalam kerangka otonomi daerah di Indonesia, sudah tentang dalam kerangka berfikir sebagai Negara Kesatuan Republik Indonesia (NKRI). Fahmi Amrusyi mengatakan:27 "Dalam penyelenggaraan pemerintahan di negara kesatuan, dapat dibedakan dalam 2 (dua) bentuk, yaitu: (1) Negara Kesatuan dengan sistem sentralisasi, dan (2) Negara Kesatuan dengan sistem desentralisasi. Dalam negara kesatuan dengan sistem sentralisasi, segala sesuatu dalam negara langsung diatur dan diurus oleh Pemerintah Pusat dan daerahdaerah hanya tinggal melaksanakan segara apa yang telah diinstruksikan oleh Pemerintah Pusat. Sedangkan dalam Negara Kesatuan dengan sistem desentralisasi, kepada daerah-daerah diberikan kesempatan dan kekuasaan untuk mengatur dan mengurus rumah tangganya sendiri (otonomi daerah) yang dinamakan dengan Daerah Otonom.

Implementasi undang-undang penataan ruang dalam sistem hukum di Indonesia, tidak bisa bersifat mandiri atau independen. Harus memperhatikanmaknadankepentinganundangundang lainnya, termasuk undang-undang pemerintah daerah. Karena bagaimanapun penataan ruang, harus menyerasikan kepentingan pemerintah pusat, pemerintah provinsi, dan pemerintah daerah kabupaten/ kota,dengan mencermati, memahami dan menyelaraskan peraturan perundang-undangan lainnya, melalui koordinasi yang intensif dan transparan untuk menyamakan persepsi, demi kesejahteraan dan kedamaian masyarakat Indonesia.

\section{Penutup}

Penegakan hukum terhadap penataan tata ruang, merupakan perwujudan pengamalan supremasi hukum dan kepastian hukum sesuai dengan falsafah bangsa Pancasila, UUD 1945 serta berbagai peraturan perundang-undangan yang berlaku. Pelaksanaan otonomi daerah dengan titik tolak dan titik singgung pemerintah kabupaten/kota merupakan sasaran strategis dalam penataan ruang. Demikian pula pemerintah provinsi untuk kepentingan tata ruangnya, dan pemerintah pusat melalui koordinasi yang intensif dan transparan untuk menyembatani kepentingan strategis dan juga berkepentingan umum agar penataan ruang secara mendasar dan meluas, adalah demi kepentingan masyarakat, bangsa, dan negara.

Penataan ruang tidak hanya beranjak pada Undang-Undang Nomor 26 Tahun 2007, dan Pemerintah Daerah tidak hanya mengacu pada Undang-Undang Nomor 23 Tahun 2014. Di samping itu, tetap harus memperhatikan dan mencermati berbagai undang-undang yang saling mendukung dan saling berinteraksi seperti Undang-Undang Nomor 5 Tahun 1990, UndangUndang Nomor 41 Tahun 1999, Undang-undang Nomor 3 Tahun 2004, Undang-Undang Nomor 27 Tahun 2007 jo Undang-Undang Nomor 1 Tahun 2014, Undang-Undang Nomor 32 Tahun 2009, Undang-Undang Nomor 2 Tahun 2002, dan lain-lain.

Penerapan Undang-Undang Nomor 26 Tahun 2007 tentang Penataan Ruang, dalam penegakan hukumnya, terlihat sulit untuk 
dilaksanakan secara kaku/represif. Hal mana berkenaan, perubahan peruntukan tata ruang dapat terjadi, dan dilakukan secara legal. Para pihak yang terlibat bukan saja warga masyarakat biasa, namun bisa jadi justru unsurunsur birokrasi dan aparatur negara yang melakukan untuk kepentingan kedinasan. Di sinilah problematika yang dapat terjadi dalam penegakan hukum penataan ruang.

Namun demikian, fenomena pelanggaran terhadap penataan ruang dalam berbagai aspek kehidupan termasuk otonomi daerah baik yang dilakukan warga masyarakat, termasuk kalangan pengusaha dalam negeri, dan para penanam modal asing, pemerintah daerah dan pemerintah pusat, perlu diakhiri, dan harus melalui tindakan hukum, yaitu:

Pertama, sejalan dengan dinamika kebutuhan lahan yang terus meningkat untuk berbagai kegiatan, dimungkinkan adanya dispensasi dan perubahan dalam penataan ruang, melalui produk peraturan perundangundangan yang berlaku.

Kedua, sinkronisasi dan koordinasi pelaksanaan tata ruang untuk kepentingan nasional, pemerintah pusat perlu mengadakan sinkronisasi dan harmonisasi dengan pemerintah daerah kabupaten/kota, dan provinsi.

Ketiga, forum permanen perlu dilembagakan di setiap kabupaten/kota, provinsi dan pemerintah pusat, yang melibatkan instansi terkait, LSM, dan akademisi, sekaligus selalu mengadakan sosialisasi kepada warga masyarakat menyangkut pemanfaatan tata ruang diwilayahnya. Hal itu dilakukan untuk mengantisipasi dan memberikan jalan keluar dinamisasi tata ruang untuk kesejahteraan masyarakat Indonesia dalam NKRI.

Keempat, penegakan hukum penataan ruang dalam pelaksanaan otonomi daerah, harus diselaraskan dengan obyek yang akan dikenakan sanksi. Dalam hal pemberian izin tata ruang diberikan oleh Kabupaten/Kota, sanksi dilakukan melaluipencabutan atau pembatalan Keputusan Bupati/Walikota, sedangkan dalam hal pemberian izin tata ruang diberikan oleh pemerintah daerah provinsi, sanksi dilakukan melalui pencabutan atau pembatalan Keputusan Gubernur. Sedangkan apa bila izin tata ruang diberikan oleh pemerintah pusat/ Keputusan Presiden, sanksi dilakukan melalui pencabutan atau pembatalan Keputusan Presiden. Yang pasti, suatu pengenaan sanksi adalah berjenjang, mulai dari penyitaan, denda, dan pencabutan izin. Sedangkan sanksi pidana, tetap dapat dilakukan sepanjang memenuhi unsur-unsur pidana.

\section{Daftar Pustaka}

\section{Buku}

Soekanto Soerjono \& Sri Mamudji. Penelitian Hukum Normatif Suatu Tinjauan Singkat (Jakarta: Radja Grafindo Persadam 2006).

Soekanto Soerjono. Faktor Yang mempengaruhi Penegakan Hukum (Jakarta: Rajawali Pers, 1983).

Ridwan Juniarso \& Achmad Sodik. Hukum Tata Ruang Dalam Konsep Kebijakan Otonomi Daerah (Jakarta: PT Rineka Cipta Cetakan III, Oktober 2016).

Ubchi Imam. Judicial Review Perda Pajak dan Retribusi Daerah (Jakarta: Sinar Grafika, 2012).

J. Kaloh. Mencari Bentuk Otonomi Daerah Suatu Solusi Dalam Menjawab Kebutuhan Lokal (Jakarta: PT Rineka Cipta, 2007).

Ranta Umbu. Konstitusionalitas Pengujian Peraturan Daerah (Yogyakarta: Genta Publishing, 2016).

Kondoatie Robert \& Roestam Syarif. Tata Ruang Air, Pengelolaan Bencana, Pengelolaan Infrastruktur, Penataan Ruang Wilayah, Pengelolaan Lingkungan Hidup (Yogyakarta: Andri, 2010).

Joesoef Daoed. Studi Strategi Logika Ketahanan dan Pembangunan Nasional (Jakarta: Buku Kompas, 2014)

MR Khairul. Untuk Desentralisasi dan Pemerintahan Daerah (Malang: Bayu Media, 2007). 
Prasodjo Eko. Referensi Kedua Melanjutkan Estafet Reformasi (Jakarta: Salemba Humanika, 2009).

PSondang Siagian. Peranan Staf Dalam Management ( Jakarta: Gunung Agung, 1982)

Sabarno Hari. Untaian Pemikiran Otonomi Daerah. Memandu Otonomi Daerah Menjaga Kesatuan Bangsa (Jakarta: Sinar Grafika, 2007).

\section{Makalah/Artikel/Laporan/Hasil Penelitian}

Harian Kompas, "Hutan Papua Penentu Emisi Indonesia", Minggu 16 April 2017.

Harian Kompas, "Kondisi 22 Aliran Sungai Kritis", Sabtu 7 Januari 2017.

Harian Kompas, "Semua Pihak Harus Tunggu Hasil Kajian", Kamis 16 Maret 2017.

LBH Jakarta, "19 Alasan Tolak Reklamasi Jakarta", https://www.bantuanhukum.or.id/web/19alasan-tolak-reklamasi-jakarta/, diakses tanggal 20 juni 2017.

\section{Peraturan}

Undang-Undang Nomor 26 Tahun 2007 tentang Penataan Ruang.
Undang-Undang Nomor 32 Tahun 2004 tentang Pemerintahan Daerah.

Undang-Undang Nomor 23 Tahun 2014 tentang Pemerintahan Daerah.

Undang-Undang Nomor 32 Tahun 2009 tentang Perlindungan Lingkungan Hidup.

Undang-undang Nomor 27 Tahun 2007 tentang Pengelolaan Wilayah Pesisir dan Pantai.

Undang-Undang Nomor 1 Tahun 2014 tentang Perubahan atas Undang-Undang Nomor 27 Tahun 2007 tentang Pengelolaan Wilayah Pesisir dan Pantai.

Undang-Undang Nomor 17 Tahun 2008 tentang Pelayaran.

Undang-Undang Nomor 2 Tahun 2002 tentang Pertahanan Negara.

Undang-Undang Nomor 5 Tahun 1990 tentang Konservasi Sumber Daya Hayati dan Ekosistemnya.

Undang-Undang Nomor 21 Tahun 2001 tentang Otonomi Khusus Provinsi Papua.

Undang-Undang Nomor 11 Tahun 2006 tentang Provinsi Aceh. 